\title{
The Connotative Component as Part of the Systemic Lexical Meaning of a Word (The Case of the Russian and Bashkir Languages)
}

\author{
Raisa Gubaydullovna Davletbaeva
}

The Faculty of Bashkir Philology, The Department of Bashkir Language and its Teaching Techniques M.Akmullah Bashkir State Pedagogical University, Ufa, Russian Federation

\section{Salima Aybulatovna Tagirova}

The Faculty of Bashkir Philology, The Department of Bashkir Language and its Teaching Techniques M.Akmullah Bashkir State Pedagogical University, Ufa, Russian Federation

Lidiya Fatikhovna Abubakirova

The Faculty of Bashkir Philology, The Department of Bashkir Language and its Teaching Techniques M.Akmullah Bashkir State Pedagogical University, Ufa, Russian Federation

Dinara Damirovna Khisamova

The Faculty of Bashkir Philology, The Department of Bashkir Language and its Teaching Techniques M.Akmullah Bashkir State Pedagogical University, Ufa, Russian Federation

Shamilya Aflyakhovna Makhmutova

The postgraduate of M.Akmullah Bashkir State Pedagogical University, Ufa, Russian Federation

Zaliya Damirovna Khanova

The postgraduate of M.Akmullah Bashkir State Pedagogical University, Ufa, Russian Federation E-mail: bspu_Imc@mail.ru.

Doi:10.5901/mjss.2015.v6n5s4p158

\section{Abstract}

This article is caused by the necessity and regularity of addressing the cultural linguistics topic, in particular the connotative vocabulary. For a long time, cultural and linguistic ties have been a major focus of the linguists' interest. It is generally accepted that culture is associated with the ideas existing and being symbolically transmitted through the language. The study examines the word as a basic unit of language that in addition to its primary content also possesses the extralinguistic content, and namely the national predicament. Each specific ethnic social environment establishes its semantic space, its linguistic and conceptual views of the world, which are characterized by the differences in the set of national and culturological marked units, including words. The authors have presented various scientific interpretations of the term "connotation," series of their lexical and semantic meanings, additional figurative-metaphorical nomination contributing to implementation of the national and cultural specificity of the ethnic group who are native speakers. Application of the anthropocentric approach to the word analysis allowed expanding the semantic contours and describing the word in its diverse connections: on the one hand, within the vocabulary of the language, on the other hand, within the context of a particular culture, which made it possible to identify the cultural connotations - the cultural identity of the Russian and Bashkir peoples, and the features of their mentality. In terms of comparative typology, a cultural linguistics analysis will allow identifying the specific features of the concepts that these two ethnic groups have of fauna, flora, and other worlds as well as of themselves comprising an important part of their linguistic view of the world.

Keywords: issue of cultural linguistics, vocabulary, word, denotation, connotative meaning, semantic nature, figurative, metaphorical meaning, connotation, symbols, attributes, ethnic group, analysis, linguistic view of the world. 


\section{Introduction}

In this study, the necessity and regularity of addressing the cultural linguistics topic, in particular the connotative vocabulary, is substantiated by the fact that in recent years, we have been facing an acute problem concerning the reframe and refinement of the concepts of the language with an analysis of its functioning that changes the perception of the rigor nature of the linguistic structures and signs. The connotative vocabulary is chosen as an object of close attention and scrutiny.

Scientific works demonstrate a considerable manifestation of disagreement with the language consideration mainly in the systemic and cultural aspect, in its distancing from the person, from the society, in which the language is functioning, and from the culture, which is expressed through the language. The works contain the attempts of synthesis, divergent approaches to the formation of a new theory of language, to the basic function of the word also covering the culturological aspects of its being and functioning.

As it is known, a word is the basic unit of language. According to the definition of Vinogradov, "the word, as a unit of vocabulary, represents the consistency of a sign, i.e. its phonetic and graphic shell, and the meaning-a specific linguistic reflection of reality" (Vinogradov, 1986). Akhmanova also provides a similar definition: "the word is a historically constituted basic unit of the phonetic structure of the language; it is a form of existence of notions that are formed as a generalized reflection of reality and consolidated within the meaning of the word", but especially emphasizes that the meaning of the word is the implementation of a notion by means of the linguistic system, which is accompanied by an additional characteristic showing the associated concepts as well as by the emotional coloring and stylistic nuance of the word (Akhmanova, 1984).

Smirnitskii (1984) drew his attention not only to the basic function of the linguistic meaning of a word, but also to its extralinguistic content, to the certain specific knowledge present in the human experience. The dependence of a lexical meaning on the factors determining it and its connection with the subject, notion, and sign was schematically depicted by the scientist in the form of a triangle: a subject - the content of a sign - a sign; and, within the lexical aspect of the word, this dependence was divided into three interrelated correlations:

- Relation to the denotatum - denotation of a word.

- Relation to the categories of logic and mainly to the notion - reference of a notion.

- Relation to the conceptual and connotative meanings of other words within the framework of a relevant lexical system - this aspect is called connotation.

Different peoples have common international notions and nationally determined meanings. Each separate national society possesses its own semantic space, which is characterized by the differences in the set of national and culturological marked units.

The lexical level of any language is capable of conveying as fully as possible the national view of the word that reflects the collective ethnic experience in the development of the surrounding reality and cultural space.

Culture is expressed in the form of materialized objects of the material and spiritual activity of a person, in the form of culture bearers, in the form of institutional links, which covert the subjective activity of individuals in an objective plan. Proceeding from the aforesaid, we can distinguish the following components of culture: civilization, socio-psychological aspect, and activity. The civilizational component of culture can be regarded as the result of human economic activity during the process of a certain community development. The socio-psychological component includes the national temper, mentality, and manifestations of morality. The activity component points to the ways of developing the reality as well as of perceiving and transmitting information. As a result, the cultural and linguistic ties cover a wide range of the culture's effect. It is this diversity of the components of culture that is the factor complicating the study of the cultural and linguistic interaction. However, the study of the interaction between language and culture is necessary.

\section{Method}

As mentioned, every ethnic group divides the material and spiritual world into certain fragments implemented during the process of cognitive activity of an individual, which are consolidated in the form of key words (concepts) as the units of the view of the world, and verbalized in the form of words and idioms in the lexical system of language. For a cultural linguistics study, it is necessary to focus on the analysis of national specificity, which is implemented through the peculiarities of the interaction between culture and language, and covers the whole system of language and the entire space of culture. An ethnic group is a bearer of the linguistic and cultural space. Such bearer is a community of people that share common territory, history, culture, language and identity, wherein the national specificity manifests itself through the following components: 
- traditions, customs, and rites as stable elements of culture;

- common culture;

- everyday standards of behavior;

- national peculiarities of thinking;

- artistic culture reflecting cultural traditions of the community;

- territorial and geographical conditions;

- peculiarities of the political and social order.

The study of the connotative component within the system of lexical meaning of the word requires a contrastivecomparative approach, since this is the approach that contributes to the identification of common and specific features.

The term of "connotation" was used in the $19^{\text {th }}$ century in the works by Mill. The philosopher explained connotation as the attributes communicated by a word. He distinguished proper names serving as a mark of an individual, and connotative ones, the definition of which is the citation of significant judgements within a given name (Mill, 1970).

More than a hundred years has passed since the introduction of the term of connotation. However, until today, linguistics has no clear understanding of the phenomenon of connotation, though there is a variety of scientific works written in this field. A set of issues still remains under discussion, such as the linguistic and speech essences of connotation, its place in the semantic structure of a word, determination of connotative components in a particular unit of speech. There are no generally accepted methods for lexicographical description of connotative words. Nor is there a clear understanding of the connotative vocabulary as a specific linguistic reflection of the reality. Teliia mentions the semantic essence of connotation and its usage in the figurative meanings (Teliia, 1986). Komlev believes that connotation is not an element of the material structure of the word or meaning, that its components are formed within the mind of a person during the process of the words-signs perception (Komlev, 2006). Kolshanskii understands connotation as the new components of the units content dominating over the original meanings and manifesting in a certain context (Kolshanskii, 2005). Apresian understands connotation of a lexical item as the insignificant but steady attributes of the expressed thereby notion that are the embodiment of the assessment accepted in this linguistic community of the existing object or fact of the reality considering that connotations usually characterize the basic or the original meanings of words, and that they materialize through the figurative meanings (Apresian, 1995). Arnol'd considers connotation as part of the systemic meaning of a sign. Connotation, naturally just like any other component of the meaning of a sign, can also be of the speech, occasional nature, but its essence cannot be reduced to the situation (Arnol'd, 1981).

An analysis of the definitions provided by the aforementioned scientists shows that Apresian and Komlev do not consider connotation as an obligatory element of the lexical meaning of words and point to the emergence of connotation during the implementation of the pragmatic or expressive function of language. On the contrary, Arnol'd and Teliia state that connotation is an obligatory structural element of lexical meaning, and focus their attention on the units of phraseological and paremiological content of the language, a characteristic feature of which is the figurative and situational motivation that is directly related to the worldview of the ethnic group as native speakers, and to the concentration of cultural connotation; and that its center is the figurative substantiation. According to Benveniste, cultural connotation makes its interpretive potency, which is the ability to serve as an indicator of belonging to a certain cultural and ethnic group (folk or nation) (Benveniste, 1974).

By analyzing the assertions of the researches mentioned, it can be concluded that basically they recognize the figuratively substantiated aspect of meaning in the categories of culture and call it the cultural connotation. Cultural connotation is an imprint of the historical and ethnic memory in the system of a language, i.e. in its most dynamic and unique system-vocabulary. It can be reflected verbally in the form of unique concepts, stereotypes, standards, symbols, frames, mythologemes, and similar signs of the national and universal culture developed by the ethnic group as native speakers (Bavinev, 2005). The nationally marked attitudes, stereotypes, and the cultural specificity of the inner form of nominative units, verbalizing relations in the conceptual view of the world, are inherent in the semantic space of a certain ethnic group.

There is also no consensus among the scientists in the field of the structure of a connotative component of vocabulary. Therefore, we can observe various approaches to the definition of this phenomenon. Let us mention several of them.

Kuznetsova considers such components as expressiveness (everything that has an effect of enhanced expression-in the broad sense, and the presence in semantics of the components that characterize the measure and degree of occurrence of certain attributes of phenomena); emotionality (this component serves for expressing evaluative emotions); evaluativity (evaluative nature from a social standpoint-standards, a set of rules: lodyr' (sluggard), brodiaga (tramp), behavior: khalturit' (to scamp), trepat'sia (to yatter), products of their activity: mesivo (medley), striapnia 
(slapdash), various social phenomena: kuter'ma (hoopla), draka (tussle)); and figurativeness (a component containing a hidden comparison and reviving our ideas of certain phenomena) (Kuznetsova, 1989).

Sternin (1987), Arnol'd (1981), Kharchenko (1976) distinguish the following attributes of connotation:

- additions to the denotative aspect of meaning;

- recurrences of connotation with respect to denotation;

- expression of the emotional, expressive, and evaluative information.

In terms of cultural components, Vorkachev distinguishes in the semantic structure of connotatively significant words the following series of lexical and semantic phenomena:

- Series 1-words including proper names, the connotation of which is based on the national and distinctive associations inherent only in the native speakers of the given language. For example, such Russian words as bereza (birch), osina (aspen), riabina (mountain ash), kalina (snowball tree), cheremukha (bird cherry tree), and vishnia (cherry tree) not only denote an object, but also evoke the emotionally ethic and esthetical associations in the Russians. They are used in fiction and folk songs, symbolize love of a woman and love relationships of young people, whereas the Bashkir people associate a lonely birch with sorrow, sadness, and loneliness of a girl or a young woman who has lost her loved one. A bird cherry tree is associated with the beauty of a girl, and its berries-with her black eyes.

Moreover, the Russians (as well as people of all nationalities living in Russia) consider the word bereza (birch) as a symbol, the personification of the Homeland. The symbolic word bereza (birch) is found in many verses and works of fiction dedicated to Russia (the Homeland), victory and war.

The national and original associations in the ethnic Russians, and now in all the people that live in Russia, including the Bashkir, are manifested in such proper names as Moskva (Moscow), Volga (the Volga river); Salavat (Salavat), Agidel' (the Belaya river), Iremel' (the Iremel mountain); in the words and word combinations of folk origin: Il'ia Muromets (Ilya of Murom), Ivanushka-durachok (Ivan the Fool), krasna devitsa (a beautiful maiden)- in the Russians; Ural batyr (Bogatyr Ural), Khumai-kosh (the Khumai bird), Kamyr batyr (Bogatyr Kamyr)-in the Bashkir.

- Series 2-words in a figuratively extensive sense that when being used lose their correlation in the basic meanings with their lexical equivalents in other languages. For example, lastochka (swallow) is a sweet gentle word that a Russian mother uses to call her baby, while a Bashkir mother will call her child kolonsagym (foal). Such an association is connected with the attitude of a Russian woman to a swallow, which in spring used to nest over the window of her house and to sing, while in a Bashkir family, the main breadwinner was a horse, which caused great joy when foaled. Thus, this reverent attitude of a Russian woman to a swallow and of a Bashkir woman to a foal consolidated itself in the aforementioned addresses to a child.

- Series 3-words in a figurative-metaphorical sense. For example, in the literal sense, the word tiufiak means a sack stuffed with straw (a mattress). In the figurative sense, the Russians use this word to name a sluggish, weak-willed person; the Bashkir call such a person khyiyr bugy, which means the cow manure (Vorkachev, 2000).

Vardzelashvili pays special attention to the figurative-metaphorical meanings of the connotative vocabulary and distinguishes their specific features, the basic among which is the emergence of a new name as a result of the semantic transposition based on the already existing, ready units of the language. A new name is a secondary unit, which is formally and semantically motivated. Through the secondary metaphorical nomination, a person perceives and reflects the surrounding reality, conveys personal impressions and emotions associated with its objects, depicts a figurative view of the world (Vardzelashvili, 2002).

Maslova offers a different name to the words with figurative-metaphorical meaning-conceptual metaphor-and argues that it reflects the fundamental cultural values and is an instrument of thinking and understanding the world.

According to the concept by Lakoff and Johnson, "...metaphor is pervasive in everyday life, not just in language but in thought and action" (Lakoff and Johnson, 2004). Based on this concept, it can be said with confidence that metaphor is not limited to the sphere of the language, but also extends to the sphere of thought. "Human thought processes are largely metaphorical... Metaphors as linguistic expressions are possible, because there are metaphors in a person's conceptual system" (Lakoff and Johnson, 2004).

Metaphor plays an important role in understanding and structuring the reality. A person perceives the unknown through the known, the abstract through the concrete, and transfers knowledge from one content-related area to another. Metaphor "...is responsible for the person's ability to catch and create similarities between very different individuals and classes of objects" (Apresian, 1995).

Metaphorical nomination is only possible in the context. Normally, such a unit in terms of expression is represented by two components (zolotye volosy (golden hair) - yellow hair).

It is acceptable to build figurative semantic fields representing an aggregate of the figurative lexical units that share common components (attributes) in meaning. These fields represent a nationally colored linguistic view of the world. In 
turn, these semantic fields can have several microfields. For example, a phytonym tree - is a plant in the literal sense (denotation), and characterizes a person in the figurative sense (in connotation): a) the types of trees, plants: an oak (stupid), wood (senseless); b) the parts of a tree, plant: a leaf -stuck like a bur (annoying, importunate); cool as a cucumber (strong, healthy), like a squeezed orange (tired, exhausted); peppered (sharp-tongued, stinging); a hothouse flower (a weak tender person who grew up in a terrific environment); c) the tree-derived products: a match (slim), a thorn (importunate and also acid-tongued), a log (indifferent, heartless, senseless), a block (chunky, strong); d) the qualities of a tree, plant: ripe (mature, formed, the one who has reached proficiency); fruitful (the one who has many children or has attained certain success); rough (rude, uncouth, ill-mannered); evergreen (ever-young, active). Consideration of the figurative semantic fields in comparative terms using the materials from different languages will present the national identity as a more obvious aspect.

In general and in substance, the linguistic view of the world coincides with the logical reflection of the world in people's minds. A conceptual view of the world of each ethnic society depends on the territory, in which it lives, on its environment, lifestyle, occupations, customs, and traditions. If the linguistic view of the world defines a specific set of sounds and their combinations, then the conceptual view of the world represents its sensual significance passes through the people's soul, in which a certain image for a word or expression is formed and established. Thus, for example, the word podsnezhnik (a snowdrop) is perceived by the Russian people as the first flower that appears after the snow melts down, which defines the name of this flower. The focus of the Bashkir is made on another attribute of this flower-its short life, and thus it is called umyrzaia (snowdrop).

The connotation is based on a particular attribute that can be logically isolated and indicated, or on a certain general or similar impression produced by the compared objects as well as a set of attributes sometimes of quite different natures:

Dub (oak) - a stupid, illiterate, and thick-skinned person, but at the same time it characterizes a strong-built person;

Shliapa (hat) - a weak-willed, inert person, while its opposite meaning is a person of mental work;

Gus' (goose) - an unreliable, scampish person, but it takes the meaning of a proud person.

The amount of such attributes makes an emotional component that creates a generalized sensual image in the metaphor.

Vardzelashvili singled out the nouns with metaphorical meaning and broke them up into three groups according to the following attributes:

- metaphorical nomination with the semantic element that explicitly connects the metaphorical and original meanings (otdushina (outlet) -is used for exit);

- metaphorical nominations formed as a result of displacement of sensual perceptions, in which the metaphorical and original meanings are connected by a limited number of attributes perceived by the human senses (kholodnyi priem (a cold shoulder));

- metaphorical nominations actualizing the excessive elements of the semantics of an original lexical meaning spaced far away from its nuclear part (khlev (cattle shed)-a dirty apartment) (Vardzelashvili, 2002). The foundation of our study is the classification given by Vorkachev. The most frequent connotations are those that relate to characterizing a person and indicate various attributes and properties that prevail over the category of thingness. According to the results of our study, the connotative vocabulary can be defined as follows. Connotative vocabulary is a unit of cultural linguistics that possesses not only a lexical meaning, but also various kinds of emotional-expressive, metaphorical, and symbolic connotations.

The material culture and mentality, the effective continuity of the language and culture are embodied in a live national language, i.e., the language that is capable of displaying national culture mentality of the ethnic groups who are native speakers. The specificity in cultures may not affect the semantics of denotation, but it distinguishes through a connotative meaning (Davletbaeva, 2015).

The connotations characterizing a person cover all aspects of human personality: the appearance (height, constitution, facial features...), mental properties (traits of character, temperament, intelligence, emotionality...), behavior (attitude to people, reaction to a situation...).

A lot of figurative-metaphorical words (connotations) carry a certain idea usually associated with a sensual side of human consciousness, and can be used as a symbol of expressing this idea. They are not related to the reflection of any real phenomena of objective or subjective nature, but contain a hidden comparison reviving our understanding of certain phenomena.

There are significant differences between a metaphor and a symbol: a metaphor focuses on the meaning. While a symbol, for which it is not typical to be used in a predicate, on the contrary, stabilizes its form. According to the content of 
the concept itself, a symbol occupies an intermediate position between a sign and an image, being a kind of the beginning of the latter.

A symbol is a frozen image once and forever endowed with the meaning assigned thereto; it has no cognitive sense. If a metaphor promotes an image towards sense, then a symbol, which is also based on the image, brings it to the opposite direction-towards stabilizing the form. A symbol is a powerful means of influence that allows us to control emotions and feelings of an individual routing their development to a certain direction, for example, otets - nebo, mat'zemlia (the father is the Heaven, the mother is the Earth) (Homeland).

Connotative (figurative-metaphorical) vocabulary contributes to perception of the national-cultural specificity of an ethnic group as native speakers. The linguistic view of the world consists of multiple fragments. The national culture connotations serve as an important component of this linguistic view of the world.

The connotative vocabulary study is of great importance for developing human-oriented dictionaries of linguistic stereotypes, and for exploring the systems of different languages. From this perspective, the zoo-, phyto-, ornitho-, and ichthyo-morphisms as connotations become of particular significance.

An anthropocentric approach to vocabulary allows to expand the semantic contours and describe a word within the plurality of its ties: on the one hand, within the lexicon of language, and on the other hand, within the context of a particular culture, which will enable to identify the cultural connotations-the cultural identity of a Russian person or of any people, the language of which is being studied, as well as the traits of their mentality.

In terms of comparative typology, a cultural linguistics analysis will allow identifying the specific features of the concepts that the two nations have with regard to fauna, flora, and themselves comprising an important part of their linguistic view of the world.

A person's understanding of a certain animal, bird, insect, or plant has been being developed over the centuries. The nature gave certain knowledge, fascinated, horrified with its power, greatness, some kind of attributes. A man was watching the life and characters of the animal world, the growth and specific features of plants; he created for himself some images that were later assigned thereto. Thus, a certain stereotype was established, which later became a kind of symbol with a unique set of positive or negative connotations. The preference of one symbol to the other ones substantiated the spread of a certain species of animals, birds, or plants by the brightness of their traits, habits, and attributes. The world of nature organically entered the cultures of different peoples having established the specific cultural connotations. In the majority, these connotations are the same even in those ethnic groups, whose traditions, customs, and languages differ from each other, but can be individual, inherent in the understanding of only on ethnic group. The properties of symbols could change from the positive to the negative ones, or even totally get into disuse under the influence of certain changes in the traditional concepts of the ethnic group.

Thus, connotation is not a separate independent direction of cultural linguistics, but a component that includes a wide range of branches, contributes to its establishment and full disclosure of the additional meaning of a word or expression.

\section{Results}

During the study, we have developed the following algorithm for determining the connotations of words in the Russian and native languages:

- identification of semantic specificity, structure, and formation of connotative vocabulary;

- identification of the consolidation degree of the connotative content of these units in both languages;

- determination of the cultural specificity of connotative vocabulary;

- identification of sources of the cultural interpretation of the units analyzed;

- determination of the national specificity of these units by comparing them in the Russian and Bashkir languages. languages.

Let us examine the connotative vocabulary using as an example the word "dog" in the Bashkir and Russian

Denotation of the word "dog"-it is a domestic animal from the family of carnivorous mammals, which also includes wolves, foxes, etc.

Connotation of the given word indicates as follows:

1. A person who had to move actively while performing a certain kind of work (ustal kak sobaka (tired like a dog in Rus., et shikelle arynym - in Bash.) - neutral connotation, the meaning is the same both in the Russian and Bashkir languages. 
2. People who live in constant conflict (zhit' kak koshka s sobakoi (live a cat and dog life - in Rus., et menen besei shikelle - in Bash.) - negative connotation coincides.

3. A person who is not engaged in any kind of work (goniat' sobak (to chase dogs) - in Rus., et khugaryp - in Bash.) - negative connotation - the meaning is the same both in Russian and Bashkir languages.

4. A person who is competent in some kind of business (sobaku s"el (to be a dab hand at smth.) - in Rus., absent in the Bashkir language) - positive connotation.

5. A thing that a person does not need (kak sobake piataia noga (to need smth. like a dog needs a fifth leg) - in Rus., absent in the Bashkir language) - neutral connotation.

6. To accuse a person in what he is not guilty (veshat' sobak na kogo-to (to hang all dogs on someone-to unfairly place all the blame on someone) - in Rus., absent in the Bashkir language) - negative connotation.

7. Figuring out the main reason of a particular action (vot gde sobaka zaryta (that's where the dog is buried (where the trouble lies) - in Rus., absent in the Bashkir language) - neutral connotation.

8. A grudge-bearing person who likes to revenge (et-keshe - in Bash., absent in the Russian language) negative connotation.

9. A person who thinks how to play a dirty trick on smb. (etlek uilap ierei, in Bash., absent in the Russian language) - negative connotation.

10. To scold, to come down on smb. (Et tirehen bitene kaplau - in Bash., absent in the Russian language) negative connotation.

11. A great deal of smth. (Et tubyghynan - in Bash., absent in the Russian language) - neutral connotation.

12. An illegible sloppy handwriting (Et iurghalaghan keiek - in Bash., kak kuritsa lapoi (like chicken scratch) - in Rus.) - negative connotation - the meaning is the same both in Russian and Bashkir languages.

13. To put one's blame on another person (ak etteng belehe khara etke - in Bash., absent in the Russian language) - negative connotation.

14. Zloi, kak sobaka (angry like a dog) - in Rus., et shikelle usal - in Bash. - negative connotation - the meaning is the same both in Russian and Bashkir languages.

An analysis of the above-mentioned examples in the Russian and Bashkir languages shows that connotations have positive, negative, and neutral meanings.

It is possible to cite proverbs and sayings where the connotative meaning of the word "dog" is also used.

1. V svoei konure i sobaka sil'na (a dog is strong when in its own kennel). Et oiapynda koesloe. Yz oiapynda et te iulbarys-On one's own territory each person feels confident, since he is the owner of this territory.

2. Vol'no sobake na nebo laiat' (a dog is free to bark at the sky). Et oeroer bure ioeroer-To say something, but not to be listened to.

3. I sobaka pomnit, kto ee kormit (even a dog remembers who feeds it). lakshylyktyng khezeren et te bele-The good deeds always remain in our memory. The good always returns.

4. Durnaia sobaka i na veter laet (a stupid dog will bark even at the wind). Et iamany buranda khotora-A person who constantly complains on any trifles.

5. Zakhotel ot koshki lepeshki, ot sobaki - blinov (one wants tortillas from a cat and pancakes from a dog). Et auyzynan hoeiek alyp bulmas-It is said about a greedy man who would never give anything to anyone.

6. Staryi pes zria ne laet (an old dog will never bark for nothing). Kargaitan et iukka oermai-it is necessary to listen to the words of an experienced and wise person in order not to make a mistake in the future.

7. Sobaka seno ne est $i$ koze ne daet (a dog does not eat hay and does not let a goat eat it). Et besende uze le ashamai atka la birmei-It is about a person who does not need something, but will never give it to others.

8. Sobaka, chto laet - redko kusaet (the dog that barks rarely bites). Oergen et teshlemei-It is about a person who can openly express his opinion, but never harbors grudge. There is no need to be afraid of him.

9. Sobake - sobach'ia smert' (a dog's death for a dog). Etke et uleme-A bad person dies in agony.

The implementation of the study of the connotative vocabulary in terms of comparative typology, i.e. the determination of correlation and distinctiveness of the vocabulary of the two languages and cultures, will certainly help, firstly, to define the universal human aspect in the cultures, their common and distinctive national-specific features that contribute to the more profound perception of both the foreign and the domestic culture and language; secondly, to delve deeper into the linguistic view of the world of the two peoples, to understand their psychology, character, customs, rituals, and history that have found a unique embodiment in this view of the world.

The originality of the view that the representatives of each ethnic group have of this world is substantiated by the territorial, domestic, climatic, religious, and other cultural differences, and is reflected in the lexical system. The specificity of the Russian culture, its significant difference from the cultures of other peoples imposes serious challenges in 
mastering the Russian language for the students of another nationality: having understood each word, they do not perceive (or not fully perceive) the intention of the speaker. The reason for such an inadequate perception of the situation lies not in the linguistic deficit, but in the deficit of culture, the lack of information about the history and culture of the people as a native speaker. A particular difficulty is caused by the units of cultural linguistics, including the vocabulary, which comprises a national-cultural component of meaning determining the necessity to look at the problem of correlation between the views of the world as at the implementation of the cognitive differences in the nominative units of language (words).

\section{Conclusions}

The effective work on mastering by the students of the national-cultural component of the meaning of words will be as follows:

- it will contribute to the qualitative improvement of teaching the Russian and Bashkir languages, of understanding epy language as a phenomenon of culture, and of the knowledge of national specificity of a linguistic view of the world;

- it will contribute to the preparing students for a conscious staying and performing activities in a certain culturalhistorical space;

- it will allow us to intensify the process of the intercultural communication between the representatives of the Russian and other national cultures, and to support proper perception of the meaning of an utterance;

- it will contribute to the acquaintance of the students with the ethno-psychological characteristics and behavioral patterns of the people as a native speaker, to overcome the emerged cross-cultural contradictions at their distant differences. In turn, such a cultural linguistics approach serves as an additional means of motivation for studying language as a guide to the world of another culture.

The nominative units of the cultural linguistics, including the connotative vocabulary, will provide for the establishment of figurativeness reflecting the objective reality through the figurative-semantic system of linguistic means that reproduce the real view of life.

A Russian language teacher faces a serious challenge: to convey to the students and to intensify the national culture associations inherent in native speakers.

\section{References}

Akhmanova, O.S. (1984). Nekotorye voprosy semantiki v sovremennom iazykoznaniia [Some Problems of Semantics in Modern Linguistics] (pp. 176). Moscow: Russkii lazyk [in Russian].

Apresian, Iu.D. (1995). Konnotatsiia kak chast' paradigmatiki slova [Connotation as Part of Paradigmatics of a Word] (pp. 156-177). Izbrannye trudy. Vol. 2: Integral'noe opisanie iazyka, sistemnaia leksikografiia - Selected Works, Vol.2: Integral Description of Language, Systemic Lexicography.

Arnol'd, I.V. (1981). Stilistika sovremennogo angliiskogo iazyka [Stylistics of the Contemporary English Language] (pp. 296). Leningrad: Nauka [in Russian].

Arutiunova, N.D. (1990). Metafora. Lingvisticheskii entsiklopedicheskii slovar' [Metaphor. Linguistic Encyclopedic Dictionary]. Moscow [in Russian].

Bavinev, R.R. (2005). Kul'turnaia konnotatsiia i paremicheskie edinitsy [The Cultural Connotation and Paremic Units]. Vestnik KazNU. Seriia filologicheskaia - The KazNU Bulletin: Phililogical Series, 8, 177-180 [in Russian].

Benveniste, E. (1974). Obshchaia lingvistika [General Linguistic] (pp. 320). Moscow: Vysshaia Shkola [in Russian].

Davletbaeva, R.G. (2015). The Selected Articles on the Methodology of the Russian Language as the Language of Interethnic Communication in the Primary and Secondary School (pp. 209). Ufa: BGPU [in Russian].

Kharchenko, V.K. (1976). Razgranichenie otsenochnosti, obraznosti, ekspressivnosti i emotsional'nosti v semantike slova [Differentiation of Evaluativity, Figurativeness, Expressiveness, and Emotionality in Semantics of the Word]. Russkii iazyk v shkole - Russian Language at School, 4 [in Russian].

Kolshanskii, G.V. (2005). Izbrannye stat'i po metodike russkogo iazyka kak iazyka mezhnatsional'nogo obshcheniia v nachal'nykh i srednikh klassakh [Correlation of Subjective and Objective Factors in Language] (pp. 229). Moscow: URSS [in Russian].

Komlev, N.G. (2006). Komponenty soderzhatel'noi struktury slova [Components of the content structure of the word] (pp. 131). Moscow: URSS [in Russian].

Kuznetsova, E.V. (1989). Leksikologiia russkogo iazyka [Lexicology of the Russian language] (pp. 216). Moscow: Vysshaia Shkola [in Russian].

Lakoff, D., \& Johnson, M. (2004). Metafory, kotorymi my zhivem [Metaphors we live by] (pp. 256). Moscow: Editorial URSS [in Russian]. Mill, J.St. Of names (1970). Theory of meanings. Prentice - Hall, 1970. 
Smirnitskii, A. I. (1984). Podrobnee o teorii slova i ego leksiko - semanticheskikh variantakh [Learn more about the theory of word and its lexical-semantic variants] (pp. 497). Moscow: Vysshaia Shkola [in Russian].

Sternin, I.A. (1987). Kommunikativnaia model' znacheniia i ee ob"iasnitel'nye vozmozhnosti [The communicative model of meaning and its explanatory power] (pp. 15-22). Voronezh: Voronezhskii Universitet [in Russian].

Teliia, V.N. (1986). Konnotativnyi aspekt semantiki (nominativnykh edinits) [Connotative Aspect of Semantics (Nominative Units)] (pp. 143). Moscow: Nauka [in Russian].

Vardzelashvili, Zh. (2002). Metaforicheskaia kartina mira v russkom iazyke [Metaphorical View of the World in Russian Language] (pp. 10-11). (PhD Thesis) [in Russian].

Vinogradov, V.V. (1986). Russkii iazyk. Grammaticheskoe uchenie o slove [Russian Language. Grammatical Theory of the Word] (pp. 640). Moscow: Vysshaia Shkola [in Russian].

Vorkachev, S.G. (2000). Lingvokul'turologiia, iazykovaia lichnost', stanovlenie: stanovlenie antropotsentricheskoi paradigmy v iazykoznanii [Cultural Linguistics, Linguistic Personality, Establishment: Establishment of the Anthropocentric Paradigm in Linguistics]. Voprosy iazykoznaniia - Issues of Linguistics, 1, 64-72 [in Russian]. 